\title{
THE RUMANIAN EARTHQUAKE OF NOVEMBER IO
}

\section{By ERNest Tillotson}

$\mathrm{O}^{\mathrm{N}}$ October 22, at about 8.30 a.m. local time, a strong earthquake with epicentre probably near Barlag shook a considerable area in Rumania (see NATURE, November 9, p. 615). In Bucharest it cracked buildings, throwing some people out of bed, also overturning movable objects. In one hotel it threw a breakfast tray fully loaded from a table to the ground. By radio and special editions of the newspapers, the people were led to expect a more intense shock, and many stayed out of doors all day. One did not come that day. It is safe to predict that an earthquake will probably reaffect an area once affected, but it is folly in the present state of seismological knowledge to predict just when and where an earthquake will occur.

The predicted return came all too soon, unexpectedly, on November 10 (see Nature, November $16, p .647$ ). It was heralded by minor tremors in various parts of the Balkan States on the night of November 9, but the terrific shock came on November 10 in the early morning. For what appeared to be an age, but actually for perceptibly five minutes, Bucharest and most of Rumania and the surrounding area shook more than they had done since 1802. The people of Bucharest knew it when, with a terrific crash, their new elevenstory Carlton flats crumpled into rubble. Nor was this all. The new building of the Foreign Ministry cracked from top to bottom. The Royal Palace and the headquarters of the Rumanian Army were severely damaged. The great pillars of the Post Office fell, and one crushed a motor-car and its occupants in the street. The gallery of the National Theatre crashed into the pit, and among other buildings two hundred were destroyed and four hundred damaged. Heavy rain fell while medical men, chemists, engineers, architects and private citizens called by the radio, assisted by firemen, the Iron Guard and the German troops, searched the wreckage for those trapped. Fires broke out and basements became flooded. More than a hundred and fifty are known to have been killed in Bucharest alone, and it is feared that thirty or more people are trapped beyond hope of rescue in the Carlton flats. More than a thousand badly damaged houses have had to be evacuated in Bucharest, and there is scarcely a house not affected in some way. The British Legation building had some of its inner walls cracked but was otherwise only slightly damaged.
Other areas in Rumania, including the oilfield towns and the port of Galati, were no less affected. At Ploësti, after a vivid flash of lightning which put the telephones out of action, the earthquake severely damaged the town hall, a hotel, and the Standard Oil Company's offices. The refineries of the Standard Oil Company also have been compelled to close for ten days while repairs are done chiefly to the pipe lines. In this town also the prefecture, the chamber of commerce, and a number of private houses were destroyed, and sulphur fumes escaped from ground fissures. The Astra Romana Oil Company plant was damaged and fires broke out. At Focsani, an oil town, 70 per cent of the houses in the centre of the town are said to be razed and hundreds of people rendered homeless. At Giurgiv, an oil port on the Danube, 65 per cent of the houses are reported destroyed. At Buzeu, about sixty miles north-east of Bucharest, hundreds of buildings have been destroyed and many people killed. Damage has been done at Ramnicue and Sarat and half the villages in the Prohava oilfields have been razed. Pangui is said to have been completely destroyed and there are twenty-three dead and seventy-one seriously injured. At Jassy, four were killed and six gravely injured. In the whole district tens of thousands of peasants are homeless and the casualties are only small because of the flimsy nature of the peasant buildings.

Damage to the oil wells themselves is uncertain at present. The only fire was quickly extinguished and the pipe lines and steel casements are being examined. The prison for political prisoners at Dostrana near Campina collapsed and about a hundred people were killed. Galati, the grain and oil port, suffered severely. The cathedral and St. Helen's church were destroyed, scores of houses severely damaged, and the casualties were reported as thirty-six killed and a hundred and thirty injured. At Rutschuk, just on the Bulgarian side of the frontier, ten houses were damaged and fifteen persons injured. At present it is difficult to assess the total damage in the whole area. Telephone communications are still interrupted, and some railways have not yet resumed operation pending the examination of tracks, lines, and bridges. A conservative estimate puts the total damage at two and a half million pounds and the casualties throughout the country as four hundred killed and eight hundred severely injured. 
Outside Rumania, the shock was felt in Sofia and many parts of Bulgaria though no damage is reported except at Rutschuk. It was also felt at Istanbul in Turkey, and in Moscow an earthquake at 4.40 a.m. local time stopped some clocks and moved some furniture. In Russian-oceupied Poland, buildings are said to have been destroyed at Kishinov and Lwow, while at Brazov in the Carpathians terror was caused.

From all this information it is possible to construct provisional isoseismal lines. The Modified Mercalli Intensity Scale of 1931 as used by the United States Coast and Geodetic Survey has been used, which ranges from 1 to 12 . A few outstanding intensities might be mentioned :

I, not felt except by a very few in especially favourable circumstances ;

5 , felt by nearly everyone; plaster cracked ; unstable objects overturned ;

10 , most masonry and frame structures destroyed with founda. tions; ground badly cracked; landslides from steep slopes ;

12, damage total; waves seen on ground surfaces; objects thrown upward into the air.

It will be seen that the shock reached intensity 10 on this scale in the epicentral area but not 11 or 12 , which are extremely rare. There are, however, some curious points. In the Carpathians at Brazov the shock had diminished to intensity 4 ; but if it was the same shock at Kishinov and Lwow in Poland, it had again increased in intensity to 8 at these places, and was even of intensity 5 in Moscow. At first sight it a p pears as though there may have been two shocks at very nearly the same time. A thorough examination of the seismo. grams from near stations would decide this point. Reports from Odessa, the grain port on the Black Sea, indicate that intensity 6 was attained there, while Belgrade, Sofia and Istanbul experienced the earthquake at intensity 3 .

Only isoseismal lines for which there is evidence have been drawn on the accom . panying map, though it appears that, with the exception of the region near Lwow, the intensity of the $\mathrm{s} \mathrm{hock} \mathrm{de} \mathrm{-}$ creased fairly regularly with increasing epicentral distance. Immediately towards the west of the epicentral area the isoseismals indicate a more rapid falling off at first than in other directions. This may be due to the geological structure. It is noticeable that the isoseismals cover a very wide area, which may point to a focus rather deeper than normal. The wide area covered by the isoseismal 10 and lack of further macroseismic 
evidence makes it difficult on these grounds to pin-point the epicentre.

It was tentatively suggested by the Meteorological Office in Sofia that the epicentre was about 210 miles from Sofia, but the centre of the inner isoseismal is at a rather greater distance than this. At the moment it is more correct to speak of an epicentral area than of an epicentral point.

I am indebted to the Rev. J. P. Rowland, S.J., for the Stonyhurst east-west Milne-Shaw seismogram of magnification 150. This has certain peculiarities which are well worth mentioning. Of the first waves to arrive, $P$ were impulsive at $01 \mathrm{~h}$. $43 \mathrm{~m} .45 \mathrm{~s}$. G.M.T., the double amplitude being nearly 4 inches. These waves had nearly died down when a very strong impulsive $S$ wave arrived at $01 \mathrm{~h} .47 \mathrm{~m} .17 \mathrm{~s}$. G.M.T. The maximum amplitude for the whole shock appeared to be an $S$ wave coming immediately after the $S$ onset. It exceeded the limits of registration (paper $9 \mathrm{in}$. wide) and the $S$ waves included some oscillations too rapid to be recorded. Father Rowland estimates provisionally that the ground oscillation at Stonyhurst was at least one eighth of an inch. The surface waves $(L)$ had a maximum double amplitude on the seismogram not exceeding 3 inches, and the waves from the shock had not quite died away after nearly 4 hours. $P P, P P P, P_{c} P, S S$, $S S S$ and $S_{c} S$ waves could be discerned but no $P S, P P S$ or $S S P$ waves. $s P, s S$ and $S R_{1}$ pulses were identified but not $p P$. Three of these latter are characteristic of earthquakes with a deeper focus than normal, and from the Brunner Chart a depth of focus of $300 \mathrm{~km}$. was estimated together with an epicentral distance of $2,330 \mathrm{~km}$, or nearly $21^{\circ}$.

I am indebted to the Director for the readings of the Kew seismogram. iP (dilatation) occurred at $01 \mathrm{~h} .43 \mathrm{~m} .18 \mathrm{~s}$. with the epicentral distance estimated at $2,090 \mathrm{~km}$. The onsets, maxima and periods of the various phases were very similar to those at Stonyhurst, and the waves could be traced for more than 4 hours. An average estimate of the initial time of the shock is November 10 , 1940 , Ih. $39 \cdot 2 \mathrm{~m}$. G.M.T. and the epicentre near latitude $45^{\circ} \mathrm{N}$., longitude $27^{\circ} \mathrm{E}$.

There has been some discussion in Great Britain, South Africa and the United States (NATURE, January 6, 1940 ; March 16, 1940 ; and Earthquake Notes, September 1940) of the possibility of the waves from one large earthquake acting as a trigger action for an earthquake in another part of the world. The matter has not been decided; but in this connexion it might be mentioned that on the day of the great Rumanian earthquake, shocks were felt in Poland and Moscow, the latter said to have been the greatest in the history of the city, also shocks in Santa Barbara (California) and Santiago de Chile.

Aftershocks of the Rumanian earthquake have been violent and frequent. Five of these were at 8.30 a.m., 8.35 a.m. and 9.30 a.m. on November 11 and two shocks on the night of November 12 . These were not registered at Kew.

Altogether, the shock constituted one of the great earthquakes of the world, but not one of the greatest. It was the greatest in Rumania since 1802, but was not so great as the Turkish earthquake of December 1939 (NATuRe, January 6, 1940).

\section{O B I T U A R I E S}

\section{Sir Herbert Wright}

$\mathrm{T}$ HE death of Sir Herbert Wright, which took place recently at Chalfont St. Giles, removes yet another of the prominent figures of the earlier days of the plantation rubber industry. Born in 1874, he was educated at the Royal College of Science, London, and went to Ceylon as scientific assistant to the director of the Royal Botanic Garden, Peradeniya. He later became acting director, and from 1900 until 1906 was controller of the Agricultural Experiment Station in Ceylon.

During this period Wright was actively engaged in the many problems of the rapidly expanding Hevea rubber industry of Ceylon, and soon came to be regarded as one of the leading authorities on the subject. The results of his work and observations on rubber were published from time to time in the Tropical Agriculturalist of Ceylon, and in a book entitled "Hevea brasiliensis or Para Rubber, its Botany, Cultivation, Chemistry and Diseases", published in 1905 ; second and third editions of this work appeared in.1906 and 1908. Another book on rubber, "Rubber Cultivation in the British Empire", from his pen appeared in 1907.

Other tropical crops besides rubber occupied Wright's attention, notably cacao. He published a work on this crop ("Theobroma Cacao or Cocoa") in 1907 , in which he presented the results of botanical and experimental work in other countries, and brought them into line with recent research in Ceylon. Citronella and lemon grass were other important Ceylon crops to engage his attention, and with the co-operation of planters he carried out a series of experiments on their growth, oil production, and general behaviour at different altitudes and in response to different soil conditions. He also made 